\title{
Stress-Corrosion Tests on High-Strength Aluminum Alloy Sheet
}

\author{
By Hugh L. Logan and Harold Hessing
}

\begin{abstract}
This paper describes stress-corrosion tests on high-strength aluminum alloy sheet. The materials investigated were $24 \mathrm{~S}-\mathrm{T}$, aged 0 to 12 hours at $375^{\circ} \mathrm{F}$; R301-T; bare and clad 75S-T; bare and clad R303-T275: and bare and clad R303-T315 alloys. The materials were exposed unstressed and stressed in tension to three-quarters of the yield strength in a sodium chloride-hydrogen peroxide solution and in a marine atmosphere. The zinc bearing alloys, 75S-T and R303-T, were also exposed, while stressed by bowing, in a boiling 6-percent $\mathrm{NaCl}$ solution. Corrosion damage was evaluted from losses in tensile strength and elongation. Commercial 24S-T material, aged 4 hours or longer, and the other alloys as supplied by the manufacturers, with the exception of the R301-T alloy, were resistant to stresscorrosion cracking.
\end{abstract}

\section{Introduction}

In 1911 Wilm [1] ${ }^{1}$ announced the preparation of an aluminum-copper-magnesium alloy that, after being rapidly cooled from approximately $500^{\circ} \mathrm{C}$, continued to increase in hardness over a period of several days. This material, in the heat-treated condition, had tensile properties approaching those of structural steel. Alloys having the same general composition and the property of hardening at room temperature after heat treatment came to be known as duralumin. By 1920 fabrication problems had been solved, and duralumin was available for use as a lightweight, high-strength structural material. Although its resistance to corrosion was generally satisfactory, it was found in some cases to be appreciably attacked on exposure to a marine atmosphere or sea water.

About 1927 a duralumin alloy sheet, sandwiched between and integrally bonded to two thin layers of commercially pure aluminum, was introduced in this country under the trade name Alclad17 S-T [2]. This material proved to be adequately resistant to corrosion even under severe corrosive conditions. However, it had somewhat lower tensile properties than the bare $17 \mathrm{~S}-\mathrm{T}$ sheet, inasmuch

${ }^{1}$ Figures in brackets indicate the literature references at the end of this paper.

Stress-Corrosion Testing of Aluminum Alloys as approximately 10 percent of the cross-sectional area was commercially pure aluminum with tensile and yield strengths much lower than those of the core material.

In 1932 [3] a duralumin type of alloy designated as $24 \mathrm{~S}$ was introduced. It contained appreciably more magnesium and slightly more copper than the $17 \mathrm{~S}-\mathrm{T}$ alloy. This alloy in the heat-treated condition (24S-T) had appreciably higher tensile and yield strengths than the $17 \mathrm{~S}-\mathrm{T}$ alloy and about the same corrosion resistance. By the end of that decade, the $24 \mathrm{~S}-\mathrm{T}$ alloy had largely replaced the $17 \mathrm{~S}-\mathrm{T}$ material as sheet material for aircraft construction. The $24 \mathrm{~S}$ alloy was supplied bare or clad, as described above.

At the outbreak of the war in Europe in 1939, it became desirable to have, for aircraft structures, aluminum alloys of higher strengths than the $24 \mathrm{~S}-\mathrm{T}$ material if they could be obtained without sacrificing corrosion resistance.

Developments of the next few years were along the following lines: (a) Increasing the strength of clad duralumin-type alloys by substituting an alloy cladding layer of higher strength than commercially pure aluminum, (b) introduction of alloys containing appreciable amounts of zinc, and (c) elevated-temperature aging of the $24 \mathrm{~S}-\mathrm{T}$ alloy. 
The R301-T alloy was of the first type. Theoretically, the use of an alloy having a more negative electrochemical solution potential than the core material should protect that material against corrosion. However, there was no service experience to indicate whether the alloy would satisfactorily replace commercially pure aluminum as the clad layer.

The 75S-T and R303-T alloys contained appreciable quantities of zinc. However, the work of Gorgan and Pleasance [5] on aluminum alloys containing 10 percent or more of zinc, and some unpublished work in this laboratory, had indicated that certain zinc-bearing alloys were susceptible to stress-corrosion cracking. The work of Forrest [6] on an alloy with 4.7 percent of $\mathrm{Zn}$, 2 percent of $\mathrm{Cu}, 2$ percent of $\mathrm{Mg}$, and 0.5 percent of $\mathrm{Ni}$ was not conclusive.

It has been known for a number of years that the hardness of the duralumin type of alloy could be increased by elevated-temperature aging. Early in the war Mozley [4] showed that the yield strength of the $24 \mathrm{~S}-\mathrm{T}$ sheet alloy, heat-treated and subsequently strained, could be appreciably increased by elevated-temperature aging. However, work done some years ago at this Bureau [7] had indicated that elevated-temperature aging of the duralumin type of alloy would probably make it susceptible to intercrystalline corrosion and stress-corrosion cracking.

The Bureau of Aeronautics of the Navy Department wished to make use of these new highstrength alloys in aircraft construction, provided they were sufficiently resistant to corrosion so that airplanes could be based on tropical islands for considerable periods of time without serious damage from corrosion. The tests described herein were undertaken at the request of that agency to determine in as short a time as possible whether these newly developed alloys were sufficiently resistant to corrosion.

Prior to the war the bare $24 \mathrm{~S}-\mathrm{T}$ alloy had proved satisfactory for use under many conditions and the clad $24 \mathrm{~S}-\mathrm{T}$ (with a 5 - or $2 \frac{1}{2}$-percent thickness of $99.3+$-percent aluminum on each surface) had proved satisfactory in aircraft exposed under severely corrosive conditions. Methods of testing the $24 \mathrm{~S}-\mathrm{T}$ alloy to predict its resistance to corrosion in service had been developed, and a large amount of data had been accumulated by various investigators. Long- time exposure tests of materials in a marine atmosphere usually indicated whether or not the material would be satisfactory in service. Laboratory tests that could be completed in a few hours or a few days frequently gave valuable information about the resistance of a material to corrosion.

The effect of stress in accelerating corrosion in certain metals and alloys is well known; it has recently been shown that under certain conditions stress may increase the damage to aluminum alloys that are exposed in a corrosive medium [8].

In order to obtain as much information as possible in a relatively short time, the resistance of these new materials to corrosion was investigated both in the laboratory and in a marine atmosphere. Specimens were exposed in corrosive media under stresses equal to three-fourths of their yield strengths. Specimens were also exposed under the same corrosive conditions, but unstressed, in order that the effect of stress in increasing corrosion damage could be evaluated. Losses in ultimate tensile strength and in percentage elongation were taken as criteria of corrosion damage.

\section{Materials}

The materials tested included the sheet alloys obtained from commercial sources, as follows: Clad 24S-T, used as a reference material; R301-T; $75 \mathrm{~S}-\mathrm{T}$, clad and bare; R303, clad and bare in the $-\mathrm{T} 275$ and $-\mathrm{T} 315$ tempers; and commercially flat $24 \mathrm{~S}-\mathrm{T}$ alloy sheet, aged for various periods in the laboratory at $375^{\circ} \mathrm{F}$. The compositions of the various commercial alloys are given in table 1 . In

TABLE 1. Chemical composition of the commercial aluminum alloys tested

(Type compositions except as indicated)

\begin{tabular}{|c|c|c|c|c|c|c|c|}
\hline Alloy & $\begin{array}{l}\text { Cop- } \\
\text { per }\end{array}$ & Zine & $\begin{array}{l}\text { Magne- } \\
\text { sium }\end{array}$ & $\begin{array}{c}\text { Manga- } \\
\text { nese }\end{array}$ & $\begin{array}{l}\text { Sili- } \\
\text { con }\end{array}$ & Iron & $\begin{array}{l}\text { Chro- } \\
\text { mium }\end{array}$ \\
\hline & $\%$ & $\%$ & $\%$ & $\%$ & $\%$ & $\%$ & $\%$ \\
\hline $24 \mathrm{~S}-\mathrm{T}^{1} \ldots \ldots$ & 4.3 & -- & 1. 4 & 0.6 & 0.27 & 0.43 & \\
\hline Clad $24 \mathrm{~S}-\mathrm{T}-$ core $^{2} \ldots$ & 4.5 & $\cdots$ & 1.5 & .6 & & & \\
\hline R301-T-core $\ldots . . .$. & 4.5 & 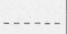 & .5 & 8 & .8 & & - \\
\hline Clad layer ${ }^{3} \ldots \ldots \ldots$ & $\ldots$ & - & 1. 1 & & .5 & & 0.25 \\
\hline $\begin{array}{l}\text { Clad and bare } 75 \mathrm{~S}-\mathrm{T}- \\
\text { core }\end{array}$ & 1. 6 & 5. 6 & 2.5 & 2 & & & .25 \\
\hline Clad layer ............ & -..... & 1.0 & 0.1 & & & & .25 \\
\hline $\begin{array}{c}\text { Clad and bare R303- } \\
\mathrm{T}-\text { core }\end{array}$ & 1.0 & 6.7 & 3. 0 & .05 & & & .13 \\
\hline Clad layer ${ }^{1} \ldots$ & - n & 2.4 & $\cdots$ & & & & \\
\hline
\end{tabular}

1 As determined at this Bureau.

2 Clad layer contains 99.3 percent or more of aluminum.

3 The composition of the clad layer of the R301 alloy has been modified somewhat since this work was done. 
addition to the alloys listed in the table an extruded aluminum alloy, of Japanese origin, containing 9.1 percent of zinc, 2.2 percent of copper and 1.4 percent of magnesium was included in some of the tests as an example of high zinc content alloys.

Tests were conducted with bare $24 \mathrm{~S}-\mathrm{T} 0.064$ in. thick; with clad $24 \mathrm{~S}-\mathrm{T}, \mathrm{R} 301-\mathrm{T}$, and $75 \mathrm{~S}-\mathrm{T}$ alloys $0.064,0.040,0.032$, and $0.020 \mathrm{in}$. thick; and with R303-T 0.125, $0.064,0.040$ and $0.020 \mathrm{in}$. thick.

\section{Methods of Test}

Two types of laboratory tests have been commonly used for determining whether aluminum alloys are subject to stress corrosion. A sodium chloride-hydrogen peroxide solution [9] $(\mathrm{NaCl}, 57 \mathrm{~g}$; $\left.\mathrm{H}_{2} \mathrm{O}_{2}(30 \%), 10 \mathrm{ml} ; \mathrm{H}_{2} \mathrm{O}, 990 \mathrm{ml}\right)$ has been used over a period of years to indicate the resistance to intercrystalline corrosion of alloys containing appreciable amounts of copper. A boiling 6-percent sodium chloride solution has been used for corrosion testing of alloys containing appreciable amounts of zinc $[10,11]$. Unpublished work at the National Bureau of Standards had indicated that in many cases the sodium chloride-hydrogen peroxide solution developed intercrystalline corrosion in alloys containing appreciable amounts of zinc. Hence, in this investigation specimens of all compositions were tested in this solution.

All materials were machined into standard ASTM flat tensile specimens with 1/2-in. reduced section. The long axes of the specimens were transverse to the direction of rolling of the sheet unless otherwise indicated.

\section{Tests in Sodium Chloride-Hydrogen Peroxide Solution}

The typical laboratory setup for testing specimens in the $\mathrm{NaCl}+\mathrm{H}_{2} \mathrm{O}_{2}$ solution is shown in figure 1. The cells were Pyrex glass cylindrical tubes, 2.4-in. outside diameter, fitted into slotted Bakelite disks, which formed the tops and bottoms of the cells. Tight seals were made by placing rubber gaskets between the Bakelite and glass. Rubber stoppers moulded with rectangular slots slightly smaller than the grip ends of the specimens completed the cell assemblies. The specimens were held in place by $1 / 4-$ in. bolts or pins passing through holes situated on the central lines of the specimens and $9 / 16$-in. from each end. Specimens up to $0.064 \mathrm{in}$. in thickness were immersed for 24 hours in the sodium chloride-hydrogen peroxide solution. One-eighth inch thick specimens were immersed for 72 hours, the solution being renewed at the end of each 24-hour period. Specimens were immersed in the corroding solution with no surface treatment other than degreasing. All clad materials were tested with the cladding intact, since the purpose of the test was to determine the resistance of the commercial alloy, not the core material, to stress-corrosion cracking. For most of the specimens tested, the temperature of the solution was maintained at $95^{\circ} \pm 1^{\circ} \mathrm{F}$ during the test. In general, three or more specimens of each material were stressed to three-quarters of the yield strength, and three specimens were immersed under the same conditions except that they were not stressed. At the close of the test period specimens were removed from the corroding solution, cleaned by scrubbing with a brush, immersed for 10 minutes in concentrated $\mathrm{HNO}_{3}$, rinsed in water, dipped in a 1.5-percent $\mathrm{NH}_{4} \mathrm{OH}$ solution, again rinsed in water and finally dried. The specimens were subsequently broken in a hydraulictype tensile-testing machine, at a cross-head speed of 0.05 to $0.1 \mathrm{in}$. per minute. Yield strengths were obtained from autographic recordings of the loadstrain diagrams obtained with a Templin-type high-magnification stress-strain recorder.

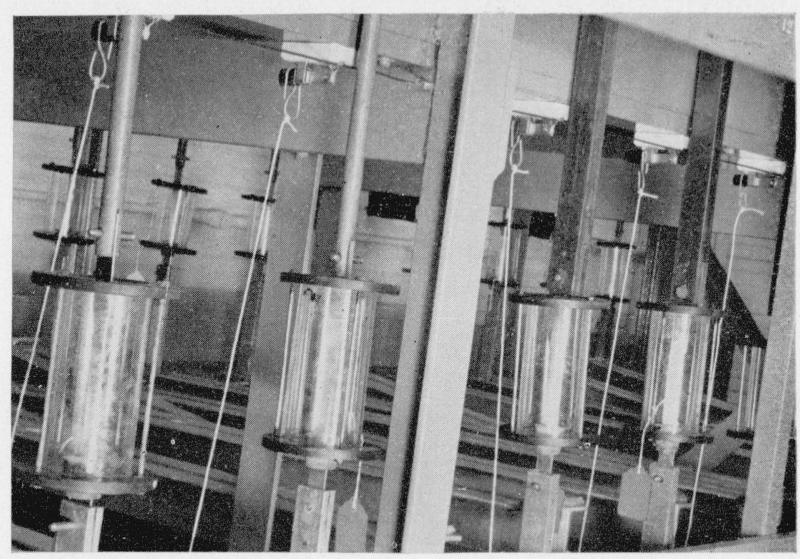

Figure 1. Laboratory stress-corrosion rack with cells for individual specimens and lever systems for stressing specimens. 


\section{Tests in Boiling 6-Percent Sodium Chloride Solution}

Specimens for test in a boiling sodium chloride solution were stressed by bowing. Bowed specimens held in monel metal fixtures and the gage used for measuring the deflections are shown in figure 2. It was necessary to bend some of the rods, such as the one shown in the upper part of figure 2 , to make it possible to insert the specimens into the large mouthed flasks shown in figure 3. The monel metal rod was clamped in a vise and the nuts were tightened until the desired deflection of the specimen was obtained. If the central section of the specimen is deflected into the arc of a circle, the stress in the outer fiber is

$$
S=\frac{4 E t d}{l^{2}},
$$

where

$S=$ stress in outer fiber

$E=$ Young's modulus

$d=$ distance from the outer fiber of the arc to the chord.

$t=$ Thickness of the specimen

$l=$ length of the chord; for a chord length of 2 in., equation (1) reduces to

$$
S=E t d \text { in } \mathrm{lb} / \mathrm{in}^{2} .
$$

$d$ was measured by means of a dial gage reading to $0.0001 \mathrm{in}$. The fixed pins at either end of the device were $2 \mathrm{in}$. apart, and the third pin, centrally located, was attached to the plunger of the dial gage. The zero reading of the gage was determined on a piece of plate glass.

Stresses calculated from the dial gage measurements were checked against those computed from wire strain-gage readings, using the average of the absolute values of the strain measured on the concave and convex sides of the specimens. The stresses corresponding to these strains were determined from the autographically recorded load-strain diagrams for the materials used. The data indicated that the stresses computed from the dial gage readings probably differed by less than 2 percent (at three-quarters of the yield strength) from the true stresses in the outer fibers.

Three bowed specimens of each material were placed in wide-mouthed flasks connected to reflux condensers as shown in figure 3. The specimens remained in the boiling solution for 14 days unless earlier failures occurred. At the conclusion of the test the specimens were removed, cleaned as indicated above and broken in tensile tests.

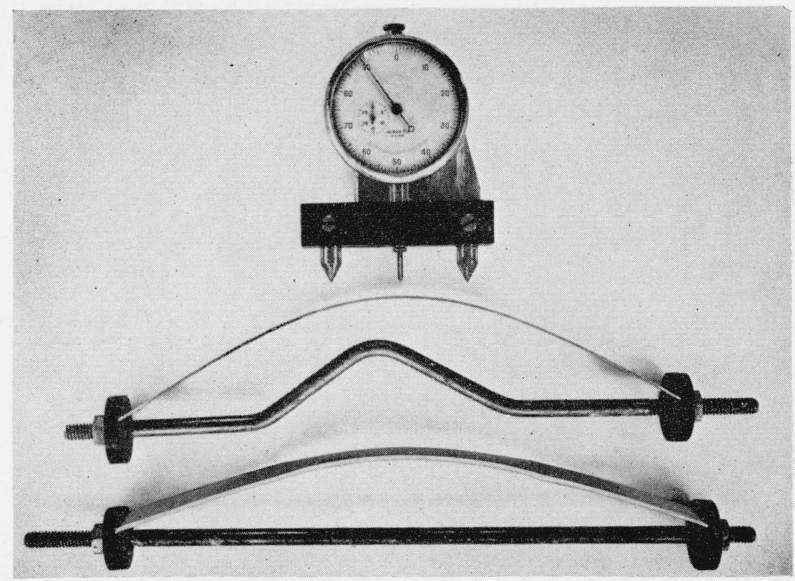

Figure 2. Bowed specimens for immersion in boiling 6 -percent $\mathrm{NaCl}$ solution and gage for determining deflection. in 2-in. gage length.

Ends of specimens were placed in slots in Bakelite washers to insulate them from the monel metal.

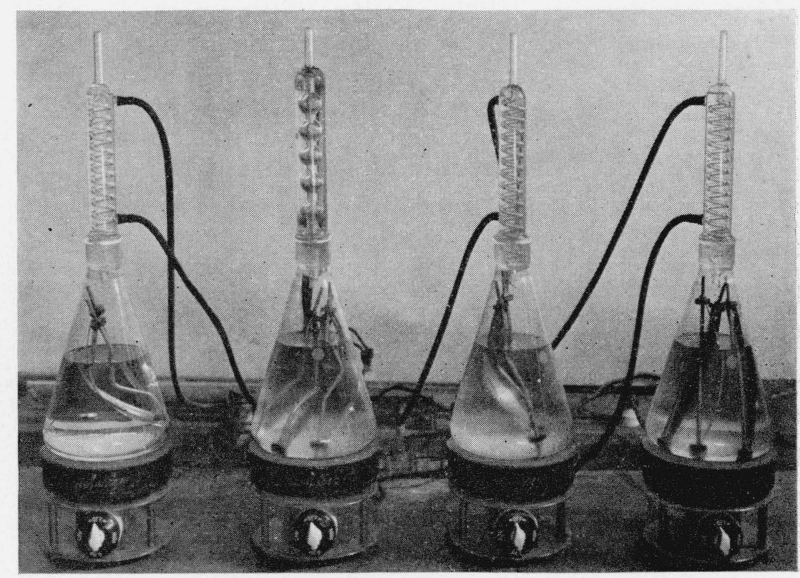

Figure 3. Bowed specimens in place in 6-percent sodium chloride solution.

\section{Marine Atmospheric Exposure Tests}

For marine atmospheric exposure stress-corrosion tests, racks similar to those used in the laboratory were installed at the Naval Air Station, Hampton Roads, Va., as shown in figure 4. The method of supporting the specimens was similar to that used in the laboratory. Three specimens from each lot of material tested were stressed to three-quarters of the yield strength by means of lever systems. Usually three unstressed specimens from the same lot were also exposed, mounted 


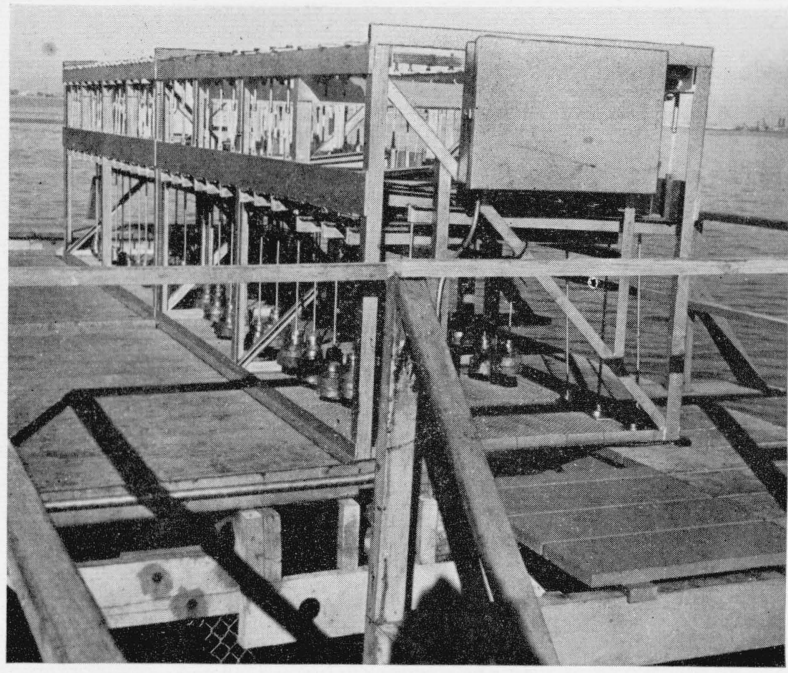

FIgURE 4. Stress corrosion racks at Hampton Roads, Va.

between the stressed specimens. Tensile specimens of the R301-T, clad and bare $75 \mathrm{~S}-\mathrm{T}$, and clad $24 \mathrm{~S}-\mathrm{T}$ alloys were anodized ${ }^{2}$ prior to the atmospheric-exposure tests. Specimens of the R303-T alloys, additional clad $24 \mathrm{~S}-\mathrm{T}$ material exposed at the same time as the R303-T, and the artificially aged $24 \mathrm{~S}-\mathrm{T}$ material were exposed without prior surface treatment except degreasing. At the close of the exposure periods, specimens were returned to the laboratory and broken in tensile tests. Metallographic examinations of coupons cut from the specimens were also made to determine the types of corrosion that had developed in the materials.

\section{Results and Discussion}

The results of laboratory tests of the various alloys in the sodium chloride-hydrogen peroxide solution are given in tables 2,3 , and 4 . Results of tests of the artificially aged $24 \mathrm{~S}-\mathrm{T}$ alloy are shown graphically in figure 5 and those of the R303-T alloy in figure 6 . Results of tests in the boiling 6-percent sodium chloride solution are given in table 5, and of the marine atmosphericexposure tests in tables 2,6 , and 7 , and shown graphically in figures $5,7,8,9,10$, and 13 .

\footnotetext{
${ }^{2}$ Specimens were anodized in a 10 -percent chromic acid bath for $1 \mathrm{hr}$, at $35^{\circ} \mathrm{C}$ and an applied voltage of $40 \mathrm{v}$.
}

\section{Tests in Sodium Chloride-Hydrogen Peroxide Solution}

The commercially heat-treated $24 \mathrm{~S}-\mathrm{T}$ alloy, as received and after aging at $375^{\circ} \mathrm{F}$, and the extruded 9.1-percent zinc alloy from a Japanese source, both 0.064 in. thick, were the most severely damaged in the chloride-peroxide solution.

The ultimate tensile strength of the $24 \mathrm{~S}-\mathrm{T}$ material (exposed without elevated-temperature aging) was reduced from 67,300 to $55,000 \mathrm{lb} / \mathrm{in}^{2}{ }^{2}$ by exposure under stress in the $\mathrm{NaCl}+\mathrm{H}_{2} \mathrm{O}_{2}$ solution for $24 \mathrm{hr}$. The tensile strength of specimens of the same material, exposed under the same conditions but not stressed, was 61,700 $\mathrm{lb} / \mathrm{in}^{2}$

Three specimens of the 9.1-percent zinc, Japanese extrusion, exposed under stress of 61,300 lb./in. ${ }^{2}$, i. e., approximately three-fourths of the yield strength, failed in $4 \mathrm{hr}$. or less. The ultimate tensile strengths of the unstressed specimens were not greatly reduced by immersion in the corroding medium.

Complete data for laboratory tests in the sodium chloride-hydrogen peroxide solution are given in tables 2, 3, and 4; data for the 24S-T and R303-T alloys are shown graphically in figures 5 and 6 . The data show that (a) stress was not effective in increasing damage to the $24 \mathrm{~S}-\mathrm{T}$ alloy that had been aged for $4 \mathrm{hr}$. or longer at $375^{\circ} \mathrm{F}$; material aged for this period or longer was at least as resistant to corrosion as the commercially heat treated, but unaged material; and (b) the R301-T, clad $75 \mathrm{~S}-\mathrm{T}$, clad R303-T275 and the clad and bare R303-T315 alloys were very resistant to the combined action of stress and corrosion in the sodium chloride-hydrogen peroxide solution. Losses in tensile properties of the thinner gages of the bare $75 \mathrm{~S}-\mathrm{T}$ and R303-T275 alloys were not large, were independent of the stress applied in the corroding medium, and are believed to be the result of pitting, which would be more effective in reducing the tensile strengths of these specimens than of the thicker ones.

Metallographic examinations of all specimens after their removal from the corroding solutions indicated that (a) the Japanese extrusion was susceptible to severe intercrystalline corrosion, (b) all of the bare $24 \mathrm{~S}-\mathrm{T}$ material was susceptible to 


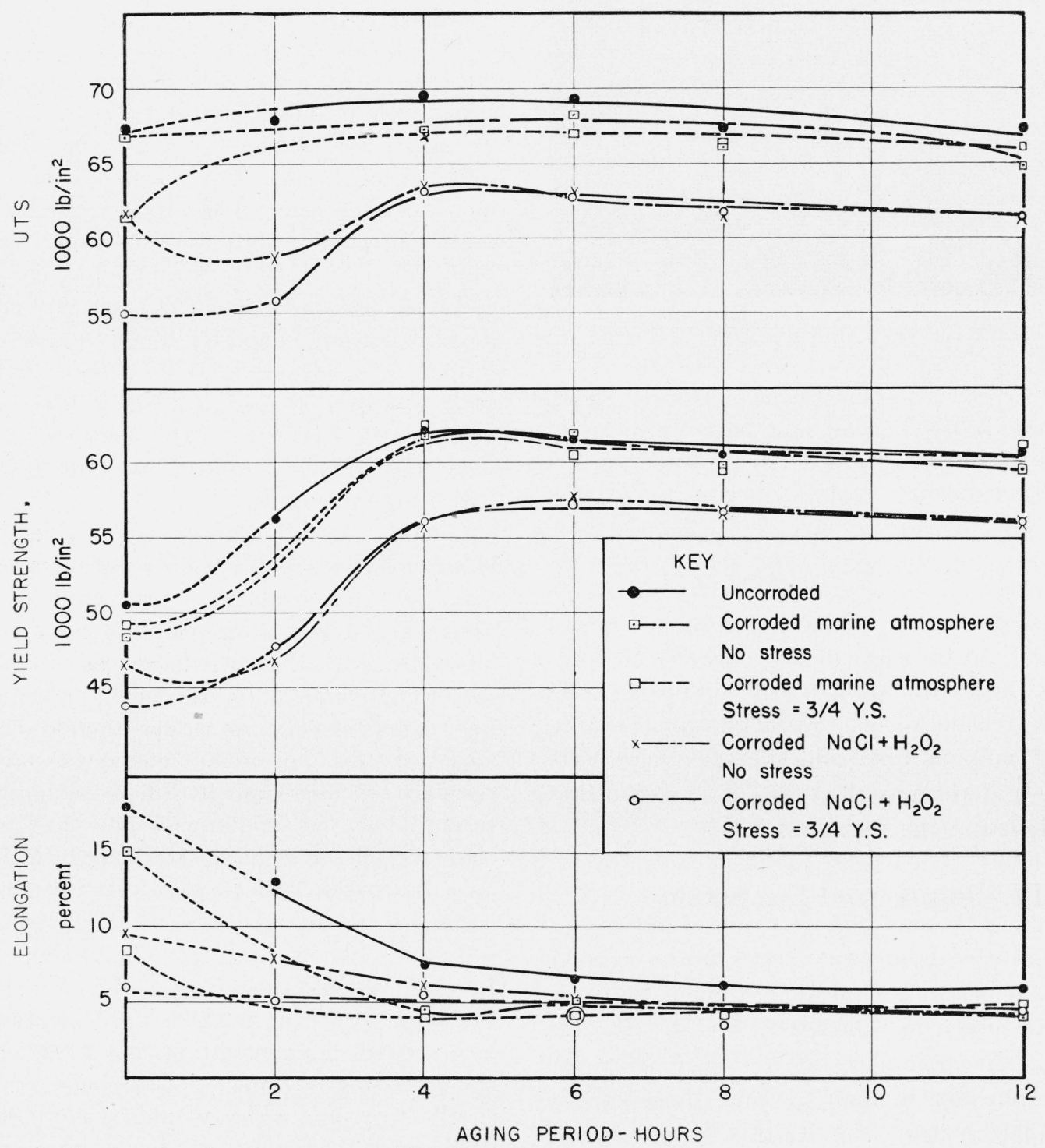

FIGURE 5. Effect of stress and corrosion on tensile properties of 0.064 -in. thick $24 \mathrm{~S}-\mathrm{T}$ material aged at $375^{\circ} \mathrm{F}$. 


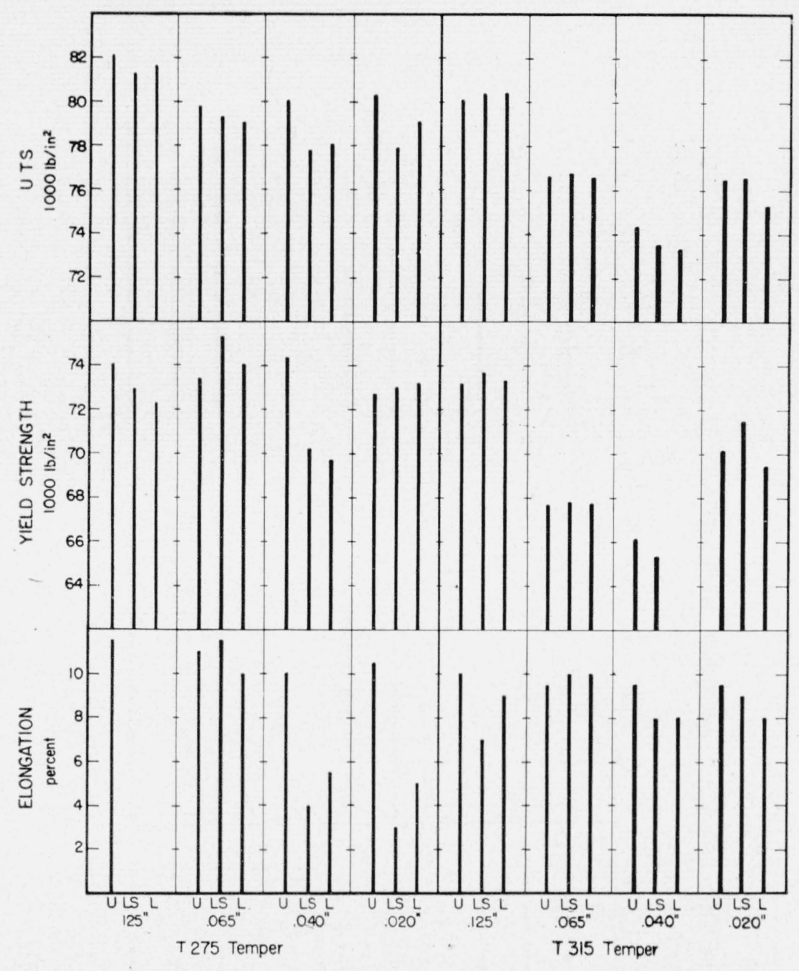

Figure 6. Effect of stress and corrosion on tensile properties of the bare R303-T275 and T315 alloys.

$U$, Uncorroded. $L S$, Corrodent: $\mathrm{NaCl}+\mathrm{H}_{2} \mathrm{O}_{2} . \quad$ Stress $=$ three-fourths of vield strength, $L$, Corrodent: $\mathrm{NaCl}+\mathrm{H}_{2} \mathrm{O}_{2} . \quad$ Stress $=0$.

intercrystalline corrosion is some degree, and (c) the R301-T, the 75S-T, and the R303-T alloys were susceptible to the pitting type of corrosion in the $\mathrm{NaCl}+\mathrm{H}_{2} \mathrm{O}_{2}$ solution. No intercrystalline corrosion was found in these materials.

\section{Tests in Boiling 6-Percent Sodium Chloride Solution}

Data in table 5 give the results of tests in boiling 6 -percent sodium chloride solution for the artificially aged $24 \mathrm{~S}-\mathrm{T}$ alloy, the bare $75 \mathrm{~S}-\mathrm{T}$ alloy, the bare and clad R303 material in the - T275 and - T315 tempers, and the extruded Japanese alloy.

Two specimens of the Japanese alloy failed during the test; one in approximately $1 \mathrm{hr}$, the second in about 1 day. No other specimens of any alloy failed. The ultimate tensile strength of the bare R303-T275 alloy (0.040 in. thick) was reduced from 80,000 to $74,300 \mathrm{lb} / \mathrm{in}^{2}{ }^{2}$. There was no significant reduction in the tensile strength of any other of the R303-T specimens. The percentage elongations of the bare R303-T275 and

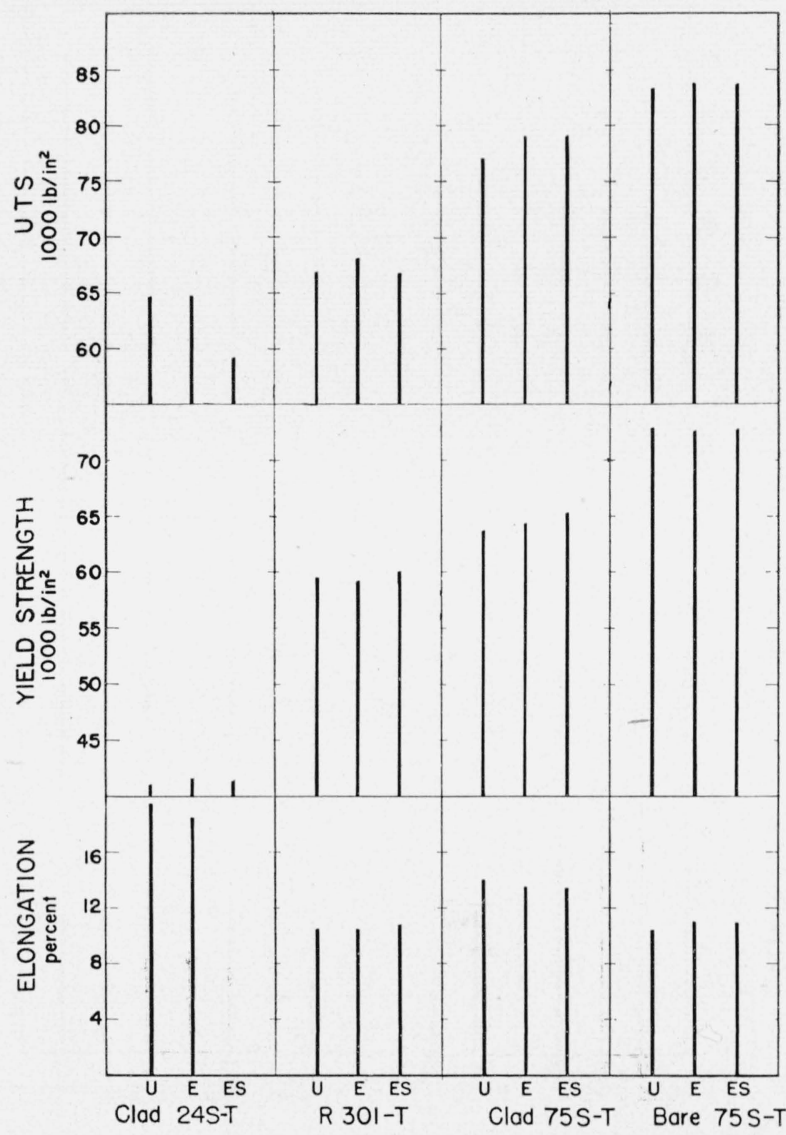

Figure 7. Effect of marine atmosphere on tensile properties of $0.064-i n$. gage anodized specimens exposed 10/27/44 to 1/26/45, 91 days.

- T315 material were reduced as the result of stress and exposure, from approximately 10 to 3 percent, and from 9.5 to 5 percent, respectively. The tensile properties of the $75 \mathrm{~S}-\mathrm{T}$ specimens were not significantly changed. The ultimate tensile strength of bare $24 \mathrm{~S}-\mathrm{T}$ material, aged $1 \mathrm{hr}$ at $385^{\circ} \mathrm{F}$, and susceptible to severe intercrystalline corrosion in the $\mathrm{NaCl}+\mathrm{H}_{2} \mathrm{O}_{2}$ solution [12], was increased slightly and the yield strength was increased appreciably, i. e., from 52,800 to 59,400 $\mathrm{lb} / \mathrm{in}^{2}$., as the result of aging in the boiling solution. The change in percentage elongation of the $24 \mathrm{~S}$ $\mathrm{T}$ specimens was about what would be expected to accompany the increase in yield strength. Hence, subsequent boiling chloride tests were confined to alloys containing appreciable amounts of zinc.

Metallographic examination of specimens of the Japanese extrusion, on removal from the boiling chloride solution, revealed severe intercrystalline 


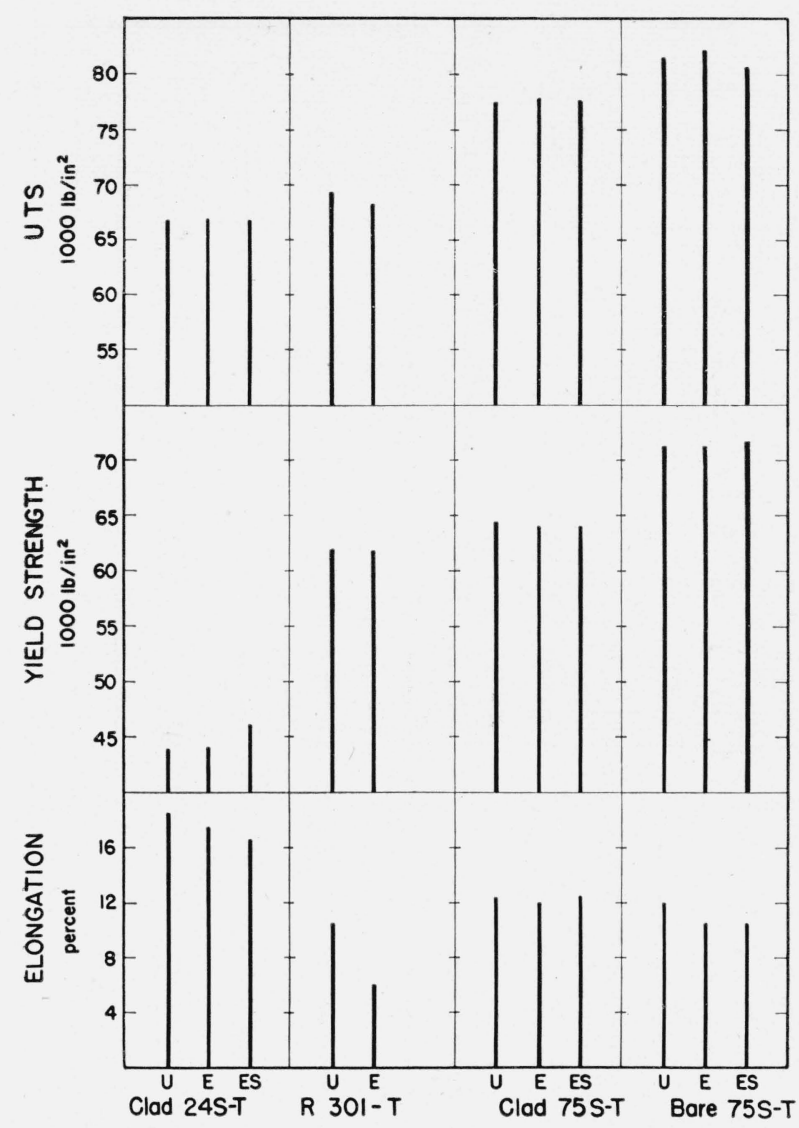

Figure 8. Effect of marine atmosphere on tensile properties of 0.040-in. gage anodized specimens exposed $1 / 24 / 45$ to $4 / 14 / 45,80$ days.

$U$, Uncorroded; $E$, exposed unstressed; $E S$, exposed stressed.

corrosion and stress-corrosion cracking. Specimens of the other materials were pitted, but no intercrystalline corrosion or evidence of stress-corrosion cracking was found.

\section{Marine Atmospheric Exposure Tests}

(a) Artificially Aged Bare 24S-T Material

Data on the bare 24S-T material aged for various times at $375^{\circ} \mathrm{F}$ are given in table 2 and shown graphically in figure 5 . The ultimate tensile strength of the commercially heat-treated (but unaged) material was reduced from 67,300 to $61,300 \mathrm{lb} /$ in. $^{2}$ and the elongation from 18 to $8 \frac{1}{2}$ percent by the combined action of stress and marine atmospheric exposure. Specimens unstressed, but otherwise exposed under the same conditions, had an average tensile strength of $66,700 \mathrm{lb} / \mathrm{in}^{2}$ and an elongation of 15 percent. Generally there was little difference in the corrosion damage to the

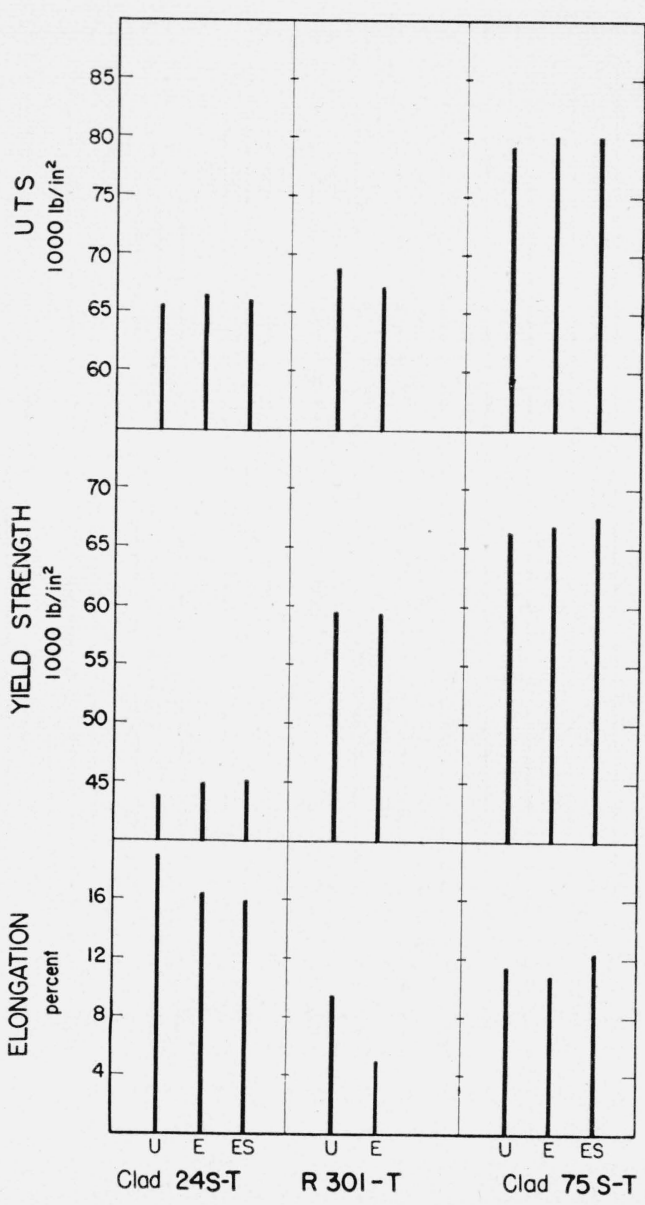

Figure 9. Effect of marine atmosphere on tensile properties of 0.032-in. gage anodized specimens exposed $10 / 27 / 44$ to $1 / 2 / 45,67$ days.

material that had been aged for $4 \mathrm{hr}$ or longer at $375^{\circ} \mathrm{F}$, whether the material was exposed stressed or unstressed. Data also indicated that material aged $4 \mathrm{hr}$ or longer was no more severely damaged as the result of stress and exposure than the commercially heat-treated but unaged material.

Intercrystalline corrosion in some degree was found in all of these specimens.

\section{(b) 75S-T, R301-T, and Clad 24S-T Alloys}

The results of marine atmospheric exposure tests on the clad $24 \mathrm{~S}-\mathrm{T}, \mathrm{R} 301-\mathrm{T}$, and bare and clad $75 \mathrm{~S}-\mathrm{T}$ alloys, 0.020 to $0.064 \mathrm{in}$. thick, all anodized prior to exposure, are given in tables 6 and 7 , and are shown graphically in figures $7,8,9$, and 10 .

The data indicated that the bare and clad $75 \mathrm{~S}-\mathrm{T}$ material of all gages was very resistant to corrosion in a marine atmosphere. 


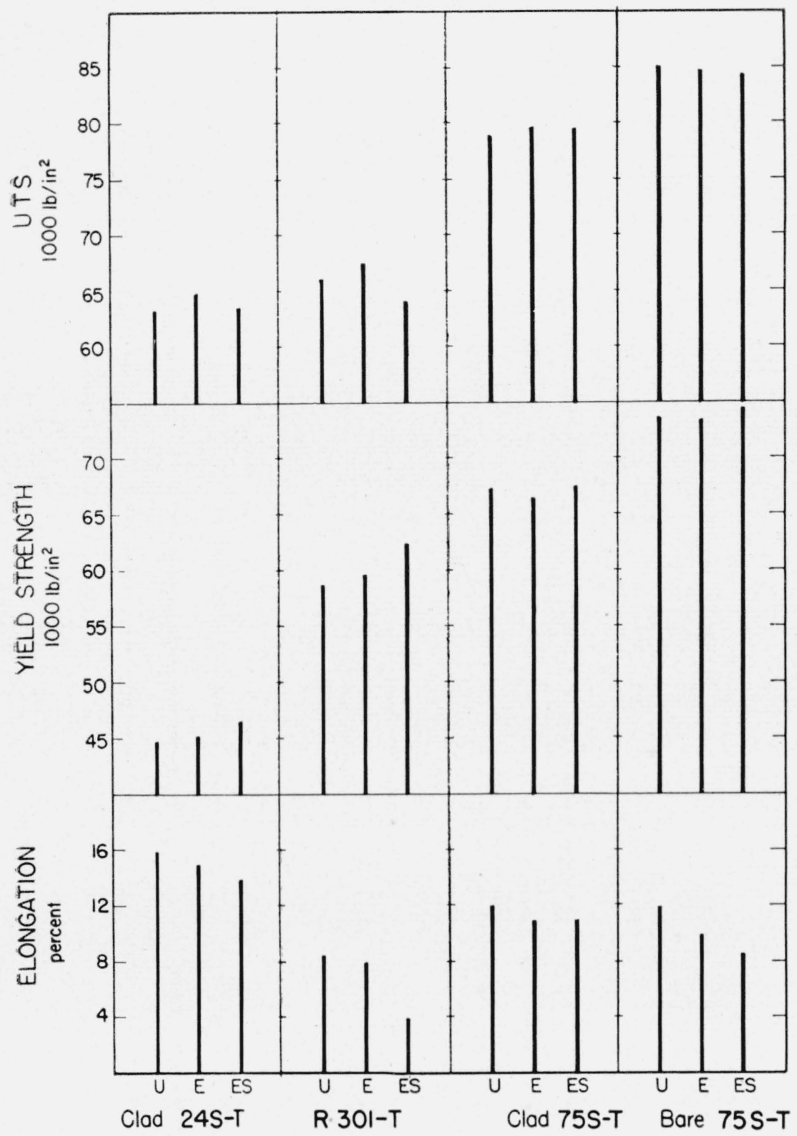

Figure 10. Effect of marine atmosphere on tensile properties of 0.020-in. gage anodized specimens exposed $1 / 26 / 45$ to $4 / 25 / 45,89$ days.

$U$, Uncorroded; $E$, exposed unstressed; $E S$, exposed stressed.

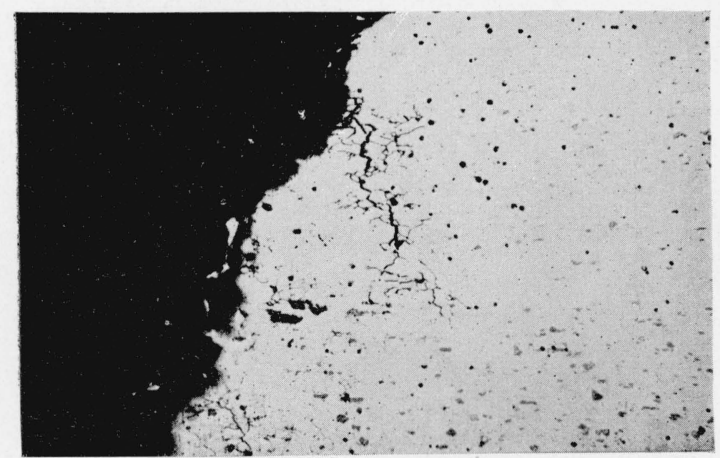

Figure 11. Intercrystalline corrosion penetrating into core material at fracture.

Plane of micrograph is parallel to and less than 0.005 in. from the exposed machined edge of specimen. Unetched, $\times 100$.

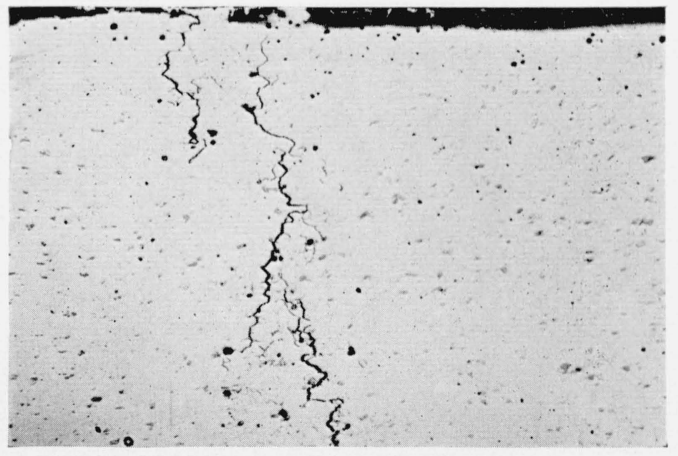

Figure 12. Beginnings of stress-corrosion cracks penetrating into core material from machined edge of specimens.

Plane of micrograph is parallel to and less than 0.005 in. from exposed edge of material. Stress-corrosion cracks are at right angles to long axis of specimen. Unetched, $\times 100$.

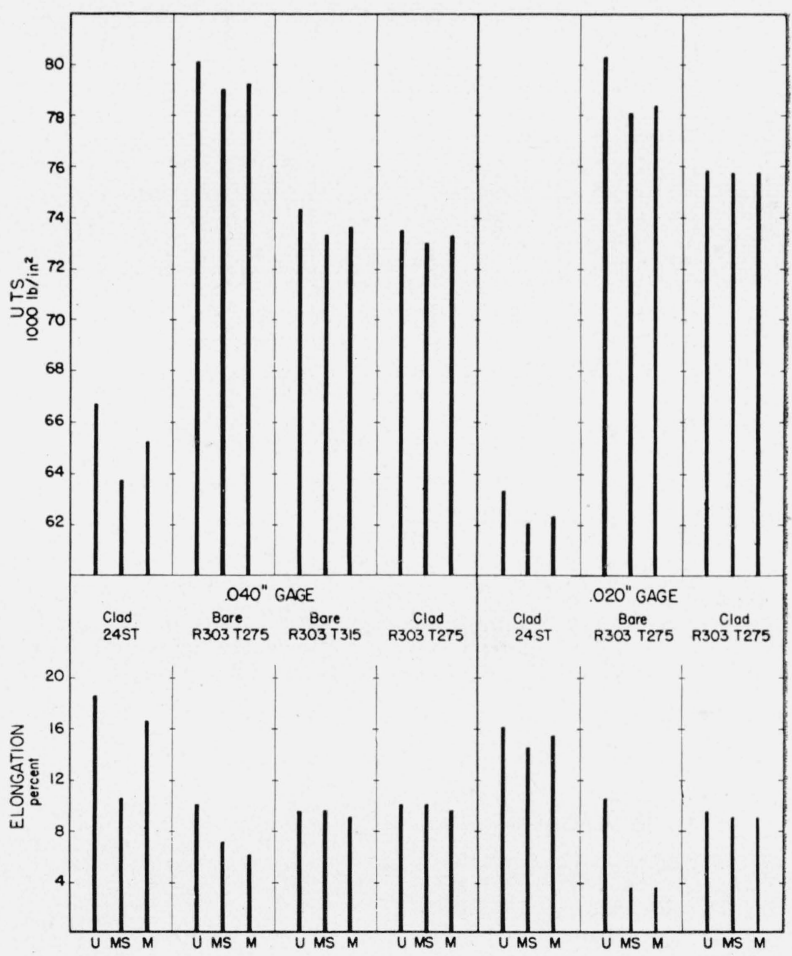

Figure 13. Comparison of ultimate tensile strength and percentage of elongation of clad $24 S-T$ material and R303-T material unstressed $(U)$ and after exposure for 56 days stressed to three-fourths of the yield strength (MS) and unstressed $(M)$ in a marine atmosphere. 


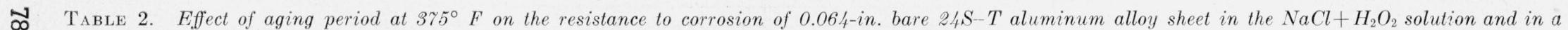
marine atmosphere

Specimens taken parallel to direction of rolling of sheet

\begin{tabular}{|c|c|c|c|c|c|c|c|c|c|c|c|c|c|c|c|c|}
\hline \multirow{3}{*}{ Aging period } & \multicolumn{3}{|c|}{$\begin{array}{l}\text { Tensile properties of uncor- } \\
\text { roded material }\end{array}$} & \multirow{3}{*}{$\begin{array}{l}\text { Average } \\
\text { applied } \\
\text { stress in } \\
\text { corroding } \\
\text { medium }\end{array}$} & \multicolumn{6}{|c|}{$\begin{array}{c}\text { Tensile properties of material after } 24 \mathrm{hr} \text { exposure in } \mathrm{NaCl}+\mathrm{H}_{2} \mathrm{O}_{2} \\
\text { solution }\end{array}$} & \multicolumn{6}{|c|}{$\begin{array}{c}\text { Tensile properties of materials after 6-weeks exposure in marine } \\
\text { atmosphere }\end{array}$} \\
\hline & \multirow{2}{*}{$\begin{array}{c}\text { Yield } \\
\text { strength } 1\end{array}$} & \multirow{2}{*}{$\begin{array}{l}\text { Ultimate } \\
\text { tensile } \\
\text { strength }\end{array}$} & \multirow{2}{*}{$\begin{array}{l}\text { Elonga- } \\
\text { tion in } \\
2 \text { in. }\end{array}$} & & \multicolumn{2}{|c|}{ Yield strength } & \multicolumn{2}{|c|}{$\begin{array}{l}\text { Ultimate tensile } \\
\text { strength }\end{array}$} & \multicolumn{2}{|c|}{ Elongation in 2 in. } & \multicolumn{2}{|c|}{ Yield strength } & \multicolumn{2}{|c|}{$\begin{array}{l}\text { Ultimate tensile } \\
\text { strength }\end{array}$} & \multicolumn{2}{|c|}{ Elongation in 2 in. } \\
\hline & & & & & A verage & $\begin{array}{l}\text { Change } \\
\text { from un- } \\
\text { corroded } \\
\text { material }\end{array}$ & A verage & $\begin{array}{l}\text { Change } \\
\text { from un- } \\
\text { corroded } \\
\text { material }\end{array}$ & A verag & $\begin{array}{l}\text { Change } \\
\text { from un- } \\
\text { corroded } \\
\text { material }\end{array}$ & A verage & $\begin{array}{l}\text { Change } \\
\text { from un- } \\
\text { corroded } \\
\text { material }\end{array}$ & A verage & $\begin{array}{l}\text { Change } \\
\text { from un- } \\
\text { corroded } \\
\text { material }\end{array}$ & A verage & $\begin{array}{l}\text { Change } \\
\text { from un- } \\
\text { corroded } \\
\text { material }\end{array}$ \\
\hline$h r$ & $\begin{array}{c}l b / i n .2 \\
350,500 \\
50,500\end{array}$ & $\begin{array}{c}l b / i n,{ }^{2} \\
67,300 \\
67,300\end{array}$ & $\begin{array}{l}\% \\
18 \\
18\end{array}$ & $\begin{array}{r}\not b / i n .^{2} \\
37,900\end{array}$ & $\begin{array}{c}l b / i n .2 \\
46,300 \\
43,600\end{array}$ & $\begin{array}{r}\% \text { of col. } .^{2} \\
8.3 \\
13.7\end{array}$ & $\begin{array}{c}l b / i n .^{2} \\
61,700 \\
55,000\end{array}$ & $\begin{array}{r}\% \text { of col. } .3^{2} \\
8.3 \\
18.3\end{array}$ & $\begin{array}{l}\% \\
9.5 \\
6.0\end{array}$ & $\begin{array}{r}\% \text { of col. } 4^{2}{ }^{2} \\
67\end{array}$ & $\begin{array}{c}l b / i n .^{2} \\
48,290 \\
49,200\end{array}$ & $\begin{array}{r}\% \text { of } \mathrm{col} .2^{2} \\
4.2 \\
2.6\end{array}$ & $\begin{array}{c}l b / \text { in }^{2} \\
66,700 \\
61,303\end{array}$ & $\begin{array}{r}\% \text { of col. } .32 \\
0.9 \\
8.9\end{array}$ & $\begin{array}{l}\% \\
15.0 \\
8.5\end{array}$ & $\begin{array}{r}\% \text { of col. } 4^{2} \\
33 \\
53\end{array}$ \\
\hline $\begin{array}{l}2 . \\
2\end{array}$ & $\begin{array}{l}56,200 \\
56,200\end{array}$ & $\begin{array}{l}67,900 \\
67,900\end{array}$ & $\begin{array}{l}13 \\
13\end{array}$ & $\begin{array}{r}0 \\
42,200\end{array}$ & $\begin{array}{l}46,800 \\
47,800\end{array}$ & $\begin{array}{l}16.7 \\
14.9\end{array}$ & $\begin{array}{l}58,200 \\
55,800\end{array}$ & $\begin{array}{l}14.3 \\
17.8\end{array}$ & $\begin{array}{l}8.0 \\
5.0\end{array}$ & $\begin{array}{l}38 \\
62\end{array}$ & & & & & & \\
\hline 4. & $\begin{array}{l}63,200 \\
63,200\end{array}$ & $\begin{array}{l}69,600 \\
69,600\end{array}$ & $\begin{array}{l}7.5 \\
7.5\end{array}$ & $\begin{array}{r}0 \\
47,400\end{array}$ & $\begin{array}{l}55,700 \\
56,100\end{array}$ & \begin{tabular}{l|}
11.9 \\
11.2
\end{tabular} & $\begin{array}{l}63,300 \\
63,200\end{array}$ & $\begin{array}{l}9.1 \\
9.2\end{array}$ & $\begin{array}{l}6.0 \\
5.5\end{array}$ & $\begin{array}{l}20 \\
27\end{array}$ & $\begin{array}{l}61,700 \\
62,500\end{array}$ & $\begin{array}{l}2.4 \\
1.1\end{array}$ & $\begin{array}{l}67,300 \\
67,100\end{array}$ & $\begin{array}{l}3.3 \\
3.6\end{array}$ & $\begin{array}{l}4.5 \\
4.0\end{array}$ & $\begin{array}{l}40 \\
47\end{array}$ \\
\hline $\begin{array}{l}6 . \\
6\end{array}$ & $\begin{array}{l}62.900 \\
62,900\end{array}$ & $\begin{array}{l}69,400 \\
69,400\end{array}$ & $\begin{array}{l}6.5 \\
6.5\end{array}$ & $\begin{array}{r}0 \\
47,300\end{array}$ & $\begin{array}{l}57,300 \\
57,709\end{array}$ & $\begin{array}{l}8.9 \\
8.3\end{array}$ & $\begin{array}{l}63,200 \\
62,900\end{array}$ & $\begin{array}{l}8.9 \\
9.4\end{array}$ & $\begin{array}{l}5.0 \\
4.0\end{array}$ & $\begin{array}{l}23 \\
39\end{array}$ & $\begin{array}{l}62,090 \\
60,500\end{array}$ & $\begin{array}{l}1.4 \\
3.8\end{array}$ & $\begin{array}{l}68,400 \\
67.090\end{array}$ & $\begin{array}{l}1.4 \\
3.5\end{array}$ & $\begin{array}{l}5.0 \\
4.0\end{array}$ & $\begin{array}{l}23 \\
39\end{array}$ \\
\hline $\begin{array}{l}8 \\
8\end{array}$ & $\begin{array}{l}60,300 \\
60,300\end{array}$ & $\begin{array}{l}67,400 \\
67,400\end{array}$ & $\begin{array}{l}6 \\
6\end{array}$ & $\begin{array}{r}0 \\
45,300\end{array}$ & $\begin{array}{l}56,600 \\
56,800\end{array}$ & $\begin{array}{l}6.1 \\
5.8\end{array}$ & $\begin{array}{l}61,500 \\
61,800\end{array}$ & $\begin{array}{l}8.8 \\
8.3\end{array}$ & $\begin{array}{l}\text { 4. } 0 \\
3.5\end{array}$ & $\begin{array}{l}33 \\
42\end{array}$ & $\begin{array}{l}59,909 \\
59,690\end{array}$ & $\begin{array}{l}0.7 \\
1.2\end{array}$ & $\begin{array}{l}66,009 \\
66,500\end{array}$ & $\begin{array}{l}2.1 \\
1.3\end{array}$ & $\begin{array}{l}4.0 \\
4.0\end{array}$ & $\begin{array}{l}33 \\
33\end{array}$ \\
\hline $\begin{array}{l}12 \ldots \\
12 \ldots\end{array}$ & $\begin{array}{l}60,800 \\
60,800\end{array}$ & $\begin{array}{l}67,500 \\
67,500\end{array}$ & $\begin{array}{l}6 \\
6\end{array}$ & $\begin{array}{r}0 \\
45,609\end{array}$ & $\begin{array}{l}55,800 \\
56,200\end{array}$ & $\begin{array}{l}8.2 \\
7.6\end{array}$ & $\begin{array}{l}61,600 \\
61,600\end{array}$ & $\begin{array}{l}8.7 \\
8.7\end{array}$ & $\begin{array}{l}4.5 \\
4.5\end{array}$ & $\begin{array}{l}25 \\
25\end{array}$ & $\begin{array}{l}59,609 \\
61,309\end{array}$ & $\begin{array}{r}2.0 \\
+3.8\end{array}$ & $\begin{array}{l}65,000 \\
66,300\end{array}$ & $\begin{array}{l}3.7 \\
1.8\end{array}$ & $\begin{array}{l}4.0 \\
5.0\end{array}$ & $\begin{array}{l}33 \\
17\end{array}$ \\
\hline $\begin{array}{l}\text { avg std. dev. } \%{ }^{4}- \\
\text { max std. dev. } \%\end{array}$ & $\begin{array}{l}1.0 \\
2.2\end{array}$ & $\begin{array}{l}0.6 \\
1.4\end{array}$ & $\begin{array}{r}9 \\
20\end{array}$ & $\begin{array}{l}\text { Unstressed } \\
\text { do }\end{array}$ & $\begin{array}{l}1.3 \\
1.8\end{array}$ & & $\begin{array}{l}0.9 \\
1.7\end{array}$ & & $\begin{array}{l}13 \\
18\end{array}$ & & $\begin{array}{r}2.3 \\
5 \\
5.1\end{array}$ & & $\begin{array}{l}1.4 \\
1.8\end{array}$ & & $\begin{array}{l}16 \\
31\end{array}$ & \\
\hline $\begin{array}{l}\text { avg std. dev. } \% \\
\text { max std. dev. } \% \text {. }\end{array}$ & & & & $\begin{array}{l}\text { Stressed } \\
\text { do }\end{array}$ & $\begin{array}{l}1.5 \\
2.1\end{array}$ & & $\begin{array}{l}0.9 \\
1.8\end{array}$ & & $\begin{array}{r}18 \\
639\end{array}$ & & $\begin{array}{r}1.7 \\
74.1\end{array}$ & & $\begin{array}{r}1.4 \\
84.6\end{array}$ & & $\begin{array}{r}20 \\
847\end{array}$ & \\
\hline
\end{tabular}

$10.2 \%$ offset from modulus line.

2 Changes in properties were negative unless preceded by + , which indicates gains.

3 Values are average of 3 or more specimens, unless otherwise indicated.

4 Standard deviations for all materials were obtained from the individual groups of specimens by using the equation

Standard deviation $=\frac{\Gamma\left(\frac{N-1}{2}\right)}{\sqrt{\left(\frac{2}{N-1}\right) \Gamma\left(\frac{N}{2}\right)}} \sqrt{\sum_{i=1}^{i=N} \frac{(X i-\bar{X})^{2}}{N-1}}$,

where $X_{i}$ are individual values, $\bar{X}$ is the average for the group as given in table above, and $N=3$ is the number of samples. Standard deviations are given in percentages of the average values, $\bar{X}$.

${ }^{5}$ Material aged $12 \mathrm{hr}$

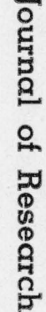

- Material aged $8 \mathrm{~h}$.

${ }^{8}$ Material not aged. 
TABLE 3. Corrosion tests in the $\mathrm{NaCl}+\mathrm{H}_{2} \mathrm{O}_{2}$ solution on bare and clad $75 S-T$ and R301-T alloys ${ }^{1}$

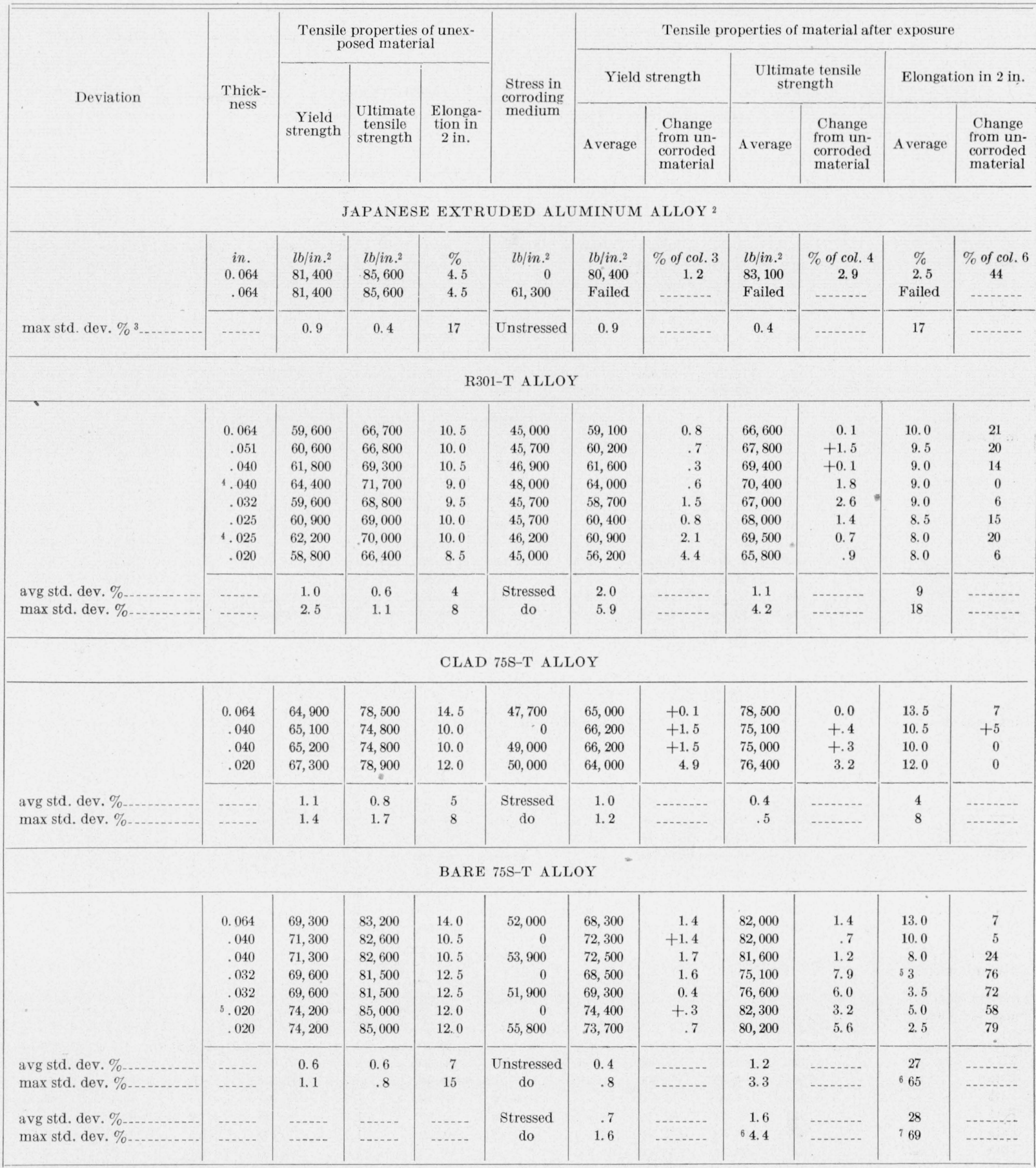

1 All specimens cut transversely to direction of rolling, unless otherwise indicated.

2 Specimens (transverse) Japanese extrusion containing $9.1 \% \mathrm{Zn}, 2.2 \% \mathrm{Cu}$, and $1.4 \% \mathrm{Mg}$ as principal alloying elements.

3 Average and maximum standard deviations are given in percentages of the average values in the table.

4 Specimens taken parallel to direction of rolling.

5 A verage of 2 specimens.

${ }^{6} 0.032$-in. specimens.

${ }^{7} 0.020$-in. specimens. 
TABLE 4.-Results of corrosion tests in $\mathrm{NaCl}+\mathrm{H}_{2} \mathrm{O}_{2}$ solution on the R303 Alloy ${ }^{1}$

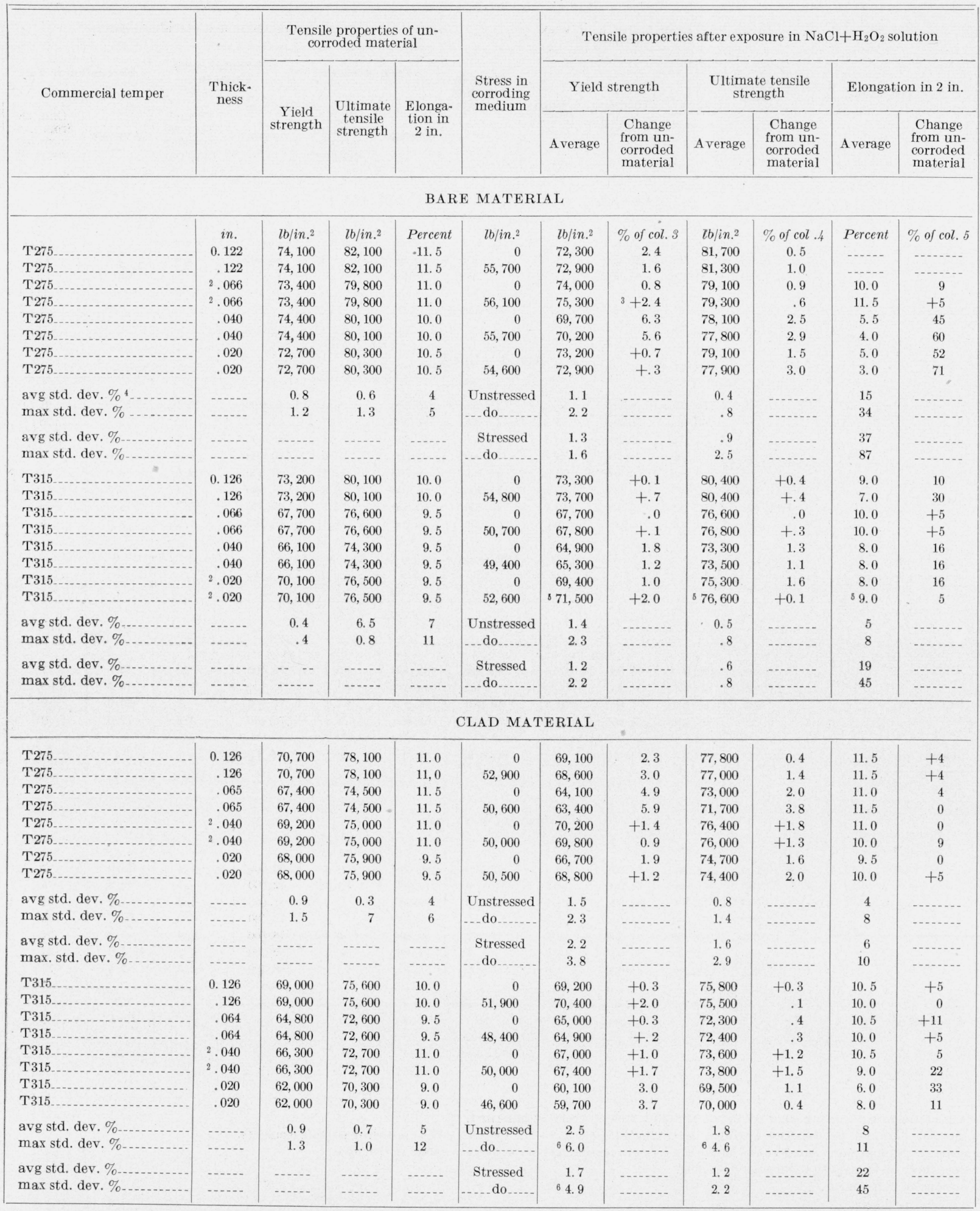

1 All specimens taken transversely to direction of rolling.

${ }^{2}$ Heat treated from " $O$ " condition at the Bureau.

$3+$ sign indicates gain.

${ }_{4}^{4}$ A verage and maximum standard deviations are given in percentages of the average values in the table. ${ }^{5}$ Average of 2 specimens. ${ }^{6} 0.020$-in. material. 
TABLE 5. Effect of boiling $\mathrm{NaCl}$ solution on specimens stressed (three-fourths of yield strength) by bowing ${ }^{1}$

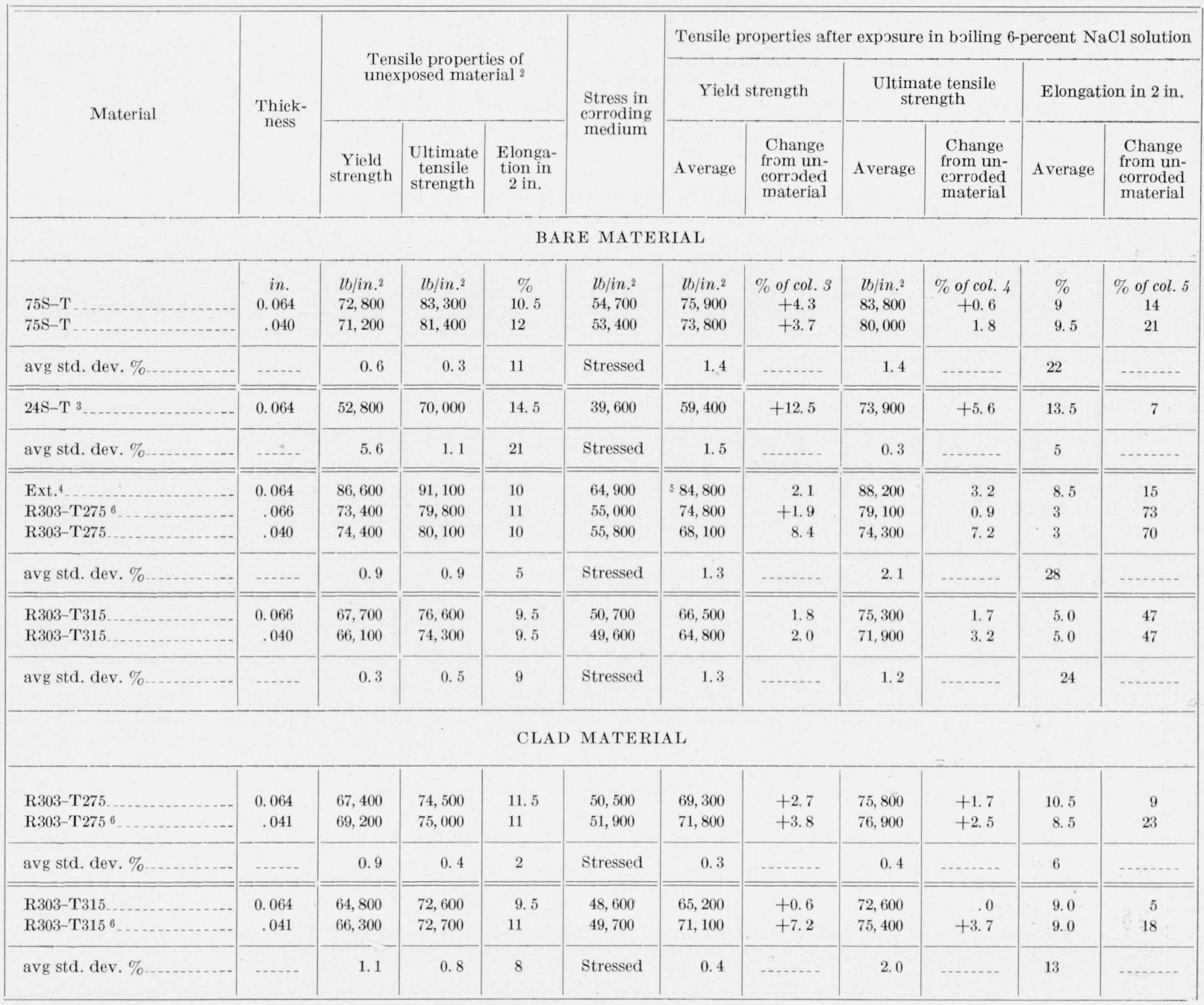

1 Specimens taken transversely to direction of rolling of sheet except Japanese extruded material.

2 Average standard deviations are given in percentages of the average values reported in the table.

${ }^{3}$ Specimens aged $1 \mathrm{hr}$ at $385^{\circ} \mathrm{F}$.

4 Specimens from Japanese extrusions contained $\mathrm{Zn}, \mathrm{Cu}$, and $\mathrm{Mg}$ as principal alloying elements.

${ }_{5}^{5}$ Single specimen; 2 specimens failed in test, 1 in approximately $1 \mathrm{hr}$, the second in about 1 day.

${ }^{6}$ Heat treated from " $O$ " condition at the Bureau. 
TABLE 6. Tensile properties of transversespecimens of clad $24 S-T, R 301-T$, and clad and bare $75 S-T$ alloys before and after exposure (anodized) in a marine atmosphere

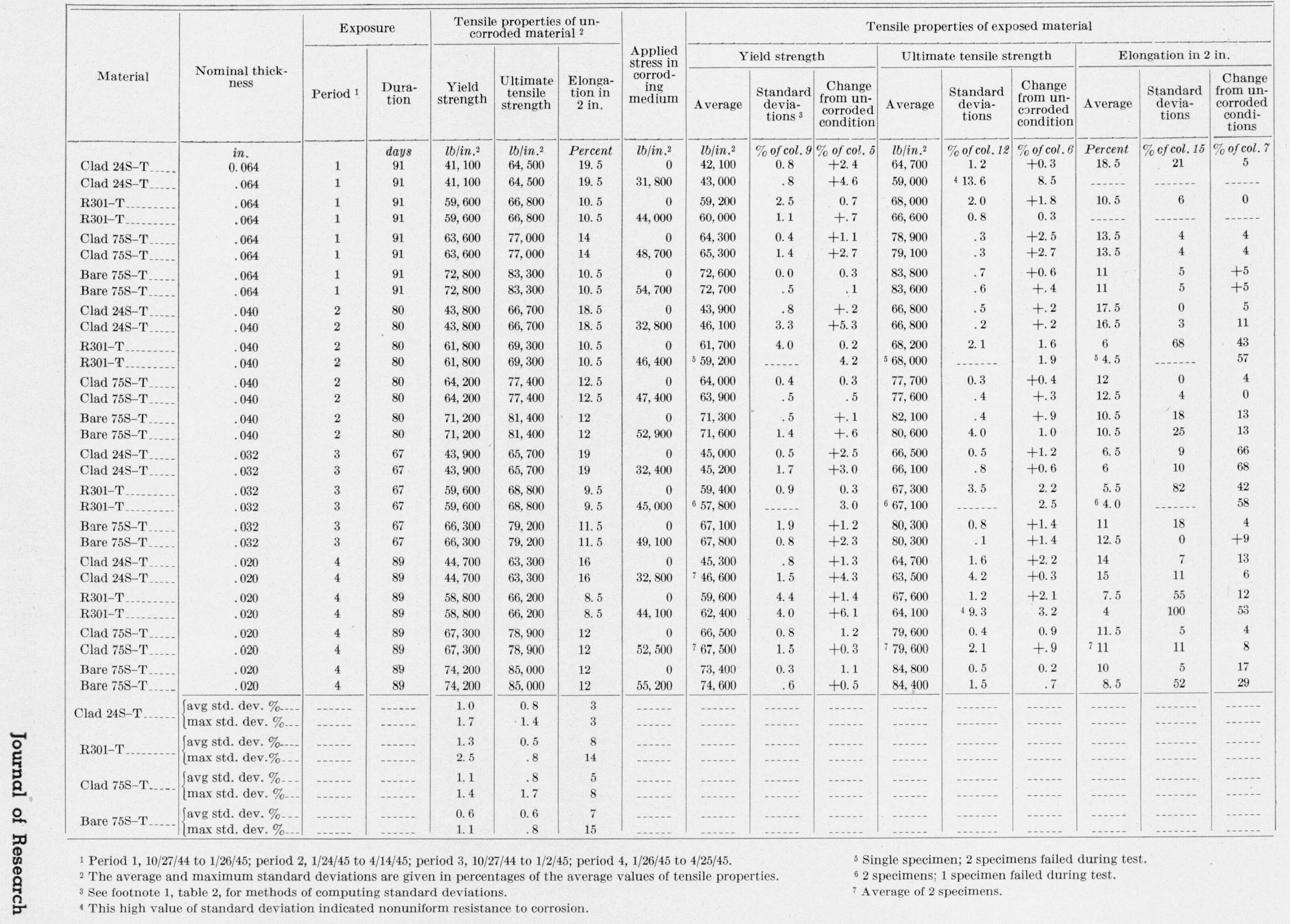




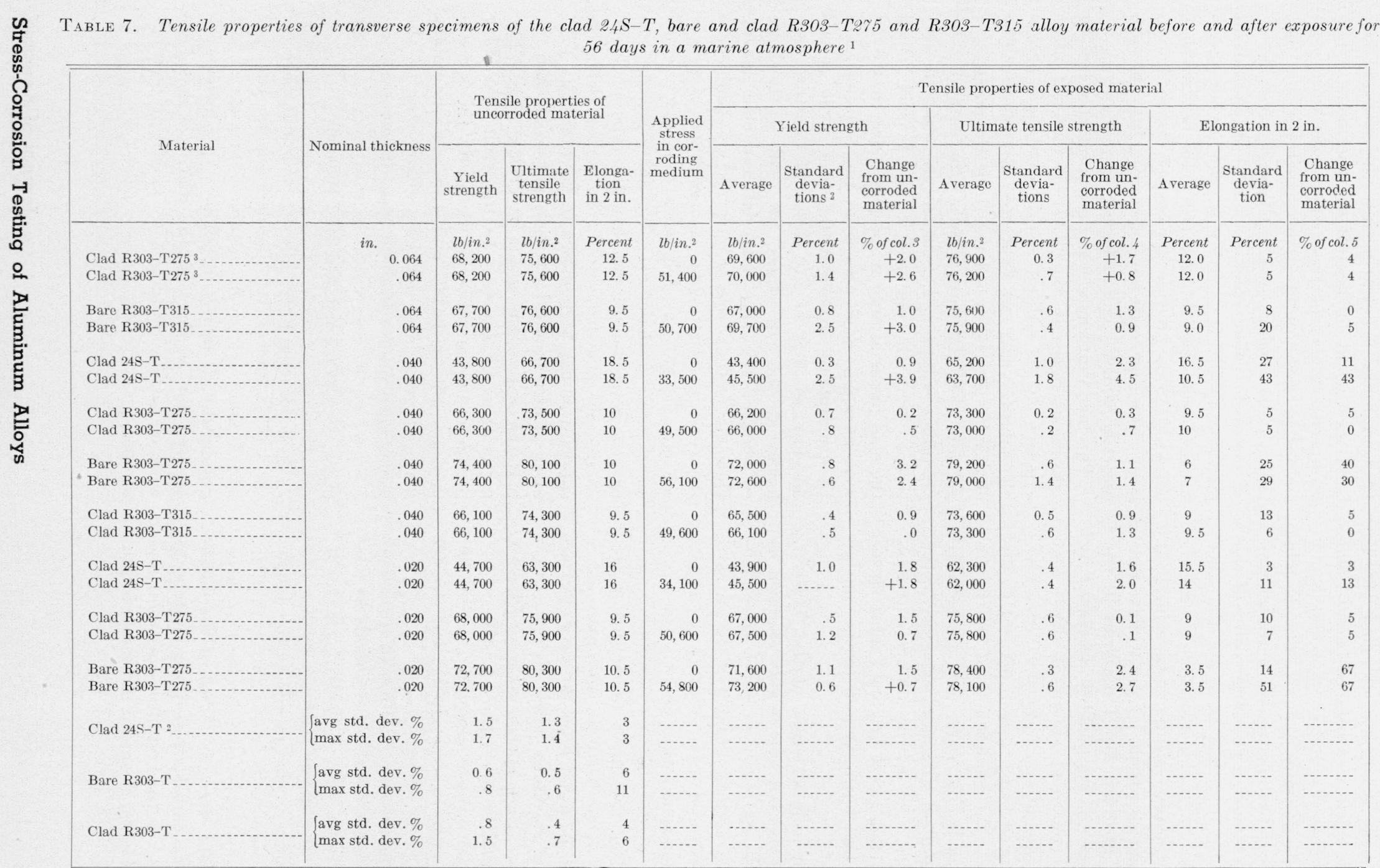

${ }^{1}$ Specimens exposed 4/26/45 to $6 / 21 / 45$ without surface preparation except degreasing.

${ }^{2}$ A verage and maximum standard deviations are given in percentages of average values given in table.

${ }^{3}$ Heat treated from " $O$ " condition at this Bureau. 
The average tensile strength of the clad $24 \mathrm{~S}-\mathrm{T}$ material, $0.064 \mathrm{in}$. thick, was reduced from 64,500 $\mathrm{lb} / \mathrm{in} .^{2}$ for the unexposed material to $59,000 \mathrm{lb} / \mathrm{in}^{2}{ }^{2}$ for material exposed under stress. The tensile strength of exposed but unstressed material was not significantly reduced. The large value of the standard deviation, 13.6 percent, for the clad $24 \mathrm{~S}-\mathrm{T}$ alloy in this gage indicates that the specimens were not uniformly resistant to the combined action of stress and corrosion. The ultimate tensile strengths of the clad $24 \mathrm{~S}-\mathrm{T}$ material in the thinner gages were not appreciably decreased by corrosion or the combined action of stress and corrosion. The elongation of the 0.032 -in. thick material was reduced from 19 to 6 percent as the result of exposure; the elongations of the 0.040 and 0.020 -in. specimens were not appreciably reduced as the result of stress and exposure in the marine atmosphere. No intercrystalline corrosion was found in the clad $24 \mathrm{~S}-\mathrm{T}$ or $75 \mathrm{~S}-\mathrm{T}$ alloy specimens after they had been exposed in the marine atmosphere.

The ultimate tensile strength of the 0.064-in. R301-T material was not appreciably changed as the result of stress and exposure. For the 0.020in. thicknesses, the tensile strength of the stressed specimens was reduced from 66,200 to 64,100 $\mathrm{lb} / \mathrm{in}^{2}$, and the elongation was reduced from 8.5 to 4 percent. Two of the 0.040 -in. specimens, and one of the 0.032 -in. specimens failed during the exposure period. One 0.040 -in. specimen failed after 38 days and the other after 80 days of exposure; the 0.032-in. specimen failed after 67 days. As indicated above, these specimens were exposed under stresses equal to about three-fourths of the yield strength; the stresses amounted to 46,400 $\mathrm{lb} /$ in. $^{2}$ for the 0.040 -in. specimens and 45,000 $\mathrm{lb} / \mathrm{in}^{2}{ }^{2}$ for the 0.032 -in. specimens.

Because there had been no failures of specimens of the other materials in exposure periods as long as 91 days, additional sets of R301-T specimens in three gages were exposed without surface protection by anodizing or other'means, in the marine atmospheric exposure racks in November of 1946. Specimens were unstressed and stressed to threefourths of the yield strength. Two of the 0.025in.-thick specimens failed after approximately 18 days of exposure. Intercrystalline-corrosion and stress-corrosion cracks, as shown in figures 11 and
12 , were found penetrating into the core material from the unclad surfaces of the specimens. The fractured surfaces of these specimens were very similar to those found in the specimens that had failed in the earlier tests. Although no evidence of stress-corrosion cracking had been found on metallographic examination of the earlier specimens, it seems possible that all of the failures that occurred in the marine atmosphere were due to intercrystalline corrosion penetrating into the core material from the cut surfaces.

The fact that there was no appreciable loss in tensile strength of the R301-T material after exposure in the sodium chloride-hydrogen peroxide solution may be explained as follows: The clad layer may be considered to be the anode of a galvanic cell, the core material the cathode, the corroding solution the electrolyte, and the external circuit the material itself. In such a cell the clad material may be preferentially destroyed with no appreciable attack on the core material. In atmospheric exposure the same type of cell develops as long as any drops of moisture, collected at the cut edges, are sufficiently large to connect the core material and clad layers. However, if the drops of moisture are confined to the core material alone, a new type of cell is set up. The galvanic cells cease to be macroscopic and become microscopic. The material adjacent to the grain boundaries in this type of heattreated alloy is believed to be impoverished in copper and has been shown to have a more negative electrochemical solution potential than the material within the grain or crystal [13]. The material at or adjacent to the grain boundary becomes the anode, the body of the crystal becomes the cathode, and the grain-boundary material goes into solution, giving rise to the well-known intercrystalline type of corrosion.

$$
\text { R303-T and Clad 24S-T Materials }
$$

Data for the R303 alloys, clad and bare, in the $-\mathrm{T} 275$ and $-\mathrm{T} 315$ tempers and for the clad $24 \mathrm{~S}-\mathrm{T}$ alloy are given in table 7 and are shown graphically in figure 13 . These specimens were exposed for 56 days in the marine atmosphere without surface protection by anodizing or other means. 
The data indicate that the R303 material, bare and clad, in both the $-\mathrm{T} 275$ and $-\mathrm{T} 315$ conditions, was generally at least as resistant to corrosion and to the combined action of stress and corrosion as the clad $24 \mathrm{~S}-\mathrm{T}$ material in the same gages.

No intercrystalline corrosion was found in either of these alloys on metallographic examination after they had been exposed in the marine atmosphere.

\section{Summary}

The results of marine atmospheric weather exposure and laboratory stress-corrosion tests described in this paper indicate that:

1. Commercially flat bare $24 \mathrm{~S}-\mathrm{T}$ aluminum alloy sheet, aged $4 \mathrm{hr}$ or longer at $375^{\circ} \mathrm{F}$, was not susceptible to stress-corrosion cracking in either laboratory tests in the $\mathrm{NaCl}+\mathrm{H}_{2} \mathrm{O}_{2}$ solution or in marine atmospheric exposure tests. Specimens aged for this period or longer were at least as resistant to the combined action of stress and corrosion as the commercially heat-treated but unaged material exposed under the same conditions.

2. Clad and bare specimens of the $75 \mathrm{~S}-\mathrm{T}$ alloy and of the clad and bare R303 alloy in the $-\mathrm{T} 275$ and $-\mathrm{T} 315$ conditions were found, after exposure periods of 60 to 90 days to be generally as resistant to corrosion or the combined action of stress and corrosion as the clad $24 \mathrm{~S}-\mathrm{T}$ alloy in the same gages.

3. The maximum loss in tensile strength of any set of specimens of the R301-T alloy immersed for $24 \mathrm{hr}$ in the $\mathrm{NaCl}+\mathrm{H}_{2} \mathrm{O}_{2}$ solution was 2.6 percent and was attributed to the pitting type of corrosion. The tensile strength of the 0.064 -in. material was not significantly reduced as the result of exposure under stress in the marine atmosphere. However, five specimens of this alloy in 0.025-, $0.032-$, and 0.040 -in. gages exposed under stress equal to three-fourths of the yield strength failed after exposure in the marine atmosphere for periods ranging from 18 to 80 days. Intercrystalline corrosion and stress-corrosion cracks, penetrating into the core material from the cut edges, were found in two of these failed specimens.

It should be noted that the failed specimens were $\frac{1}{2}$ in. wide. The failure of specimens of this width does not indicate that wide sheets of this material, exposed under stress in a marine atmosphere, will fail as the result of intercrystalline corrosion penetrating into the core material from the cut edges.

4. The results indicated that stress may appreciably increase corrosion damage to certain alloys of the duralumin type and to certain aluminum alloys containing appreciable quantities of zinc that are continually immersed for $24 \mathrm{hr}$ in the $\mathrm{NaCl}+\mathrm{H}_{2} \mathrm{O}_{2}$ solution.

5. The data indicated that a boiling 6 -percent $\mathrm{NaCl}$ solution may produce stress-corrosion cracking in alloys containing appreciable amounts of zinc. The $24 \mathrm{~S}-\mathrm{T}$ alloy, artificially aged so as to be susceptible to severe intercrystalline corrosion in the $\mathrm{NaCl}+\mathrm{H}_{2} \mathrm{O}_{2}$ solution, was not stresscracked in the boiling chloride solution.

6. The results indicate that there was generally good agreement between weather exposure and laboratory tests, except for the R301-T alloy. The contradictory results obtained in the two media on this material indicate the desirability of checking the results obtained on a clad material continuously immersed in the $\mathrm{NaCl}+\mathrm{H}_{2} \mathrm{O}_{2}$ solution with those obtained on stressed specimens. exposed to the weather.

The assistance of Houston Babb, Thomas P. Royston, Jr., and Richard C. Rohan, and the cooperation of Fred M. Reinhart and the late Willard H. Mutchler of this Bureau; of Harold E. Francis, formerly of this Bureau; and of Lts. C. A. Snavely and M. Franklin of the Naval Air Station, Hampton Roads, Va., in this investigation is gratefully acknowledged. Data on the Japanese extrusion were obtained in cooperation with the National Advisory Committee for Aeronautics. Their permission to use these data is appreciated.

\section{References}

[1] A. Wilm, Metallurgie 8, 225 (1911).

[2] E. H. Dix, Jr., NACA Tech. Note 259 (1927).

[3] Private communication from E. H. Dix, Jr., Aluminum Co. of America, to National Bureau of Standards.

[4] P. P. Mozley, J. Aeron. Sci. 10, 180 (1943).

[5] J. D. Grogan and R. J. Pleasance, J. Inst. Metals 64, 57 (1939). 
[6] G. Forrest, Metal Ind. (London) 56, 229 (1940).

[7] H. S. Rawdon, NACA Tech. Note 284 (April 1928).

[8] R. B. Mears, R. H. Brown, and E. H. Dix, Jr., Am. Symposium on Stress Corrosion Cracking of Metals, p. 329, ASTM aod AIME (1944).

[9] Army-Navy Aeronautical Specification AN-QQ-H186a, Heat treatment of aluminum alloys, process for, paragraph E-7 (b).

[10] Private communication from F. P. Somers, Bureau of Aeronautics, Navy Department, Washington.
[11] G. F. Sager, R. H. Brown, and R. B. Mears, Am. Soc. Symposium on Stress Corrosion Cracking of Metals, p. 255, ASTM and AIME (1944).

[12] H. L. Logan, H. Hessing, and H. E. Francis, J. Research NBS 38, 465 (1947) RP1788.

[13] E. H. Dix, Jr., Trans. Inst. Metals Div. Am. Inst. Mining Metal Engrs. 137, 11 (1940).

Washington, August 20, 1947. 